\title{
PEMBERDAYAAN BERBASIS SYARIAH UNTUK PEREMPUAN DI PEDESAAN MELALUI MODEL PEMBERDAYAAN GRASSROOTS MICROFINANCE SHARIAH
}

\author{
SABIRIN \\ Email : sabirin bisa@yahoo.com \\ Mahasiswa Program Magister Akuntansi \\ Universitas Padjadjaran Bandung. Jl. Dipatiukur No 35
}

\begin{abstract}
Women have an important role in national development. One way to make room for women in the national development process is by provide a space for them to be more empowered. With the empowerment of women, especially women in the countryside, hopefully they can be more productive, have the courage to take risks in business,self-sustainability, because women will tend to be more independent if they have income and economic activity. Women as part of society should be able to help themselves in different ways, especially with regard to their survival.

This paper discusses the model of Grassroots Islamic Microfinance which is a model of Islamicbased financing institution forpoor families but productive especially for women in the countryside who does nothave an opportunity to obtain financing support from commercial microfinance such as banks. This model is an effort to encourage, provide access for women on countryside especially on capitalization, so that they can be more productive and independent in an effort to prosper themselves, their families and the general public.
\end{abstract}

Key Word: Women, Empowerment, Grassroots Islamic Microfinance, Prosperous

\section{PENDAHULUAN}

Perempuan memiliki peran yang penting dalam pembangunan nasional. Salah satu cara untuk memberi ruang bagi perempuan dalam proses pembangunan nasional tersebut adalah dengan memberikan ruang bagi mereka untuk lebih berdaya. Hal ini senada dengan apa yang diungkapkan oleh Saptandari (2010), dikatakan bahwa untuk meningkatkan posisi tawar perempuan dalam meningkatkan perannya dalam pembangunan nasional adalah dengan pemberdayaan. Adapun yang menjadi tujuan pemberdayaan ini adalah untuk meningkatkan derajat kehidupan seseorang dan kesejahteraan di berbagai segi kehidupan dalam suatu lingkungan sosial.

Upaya untuk mengoptimalkan pemberdayaan perempuan serta membangkitkan masyarakat miskin, dapat ditempuh salah satunya dengan mendampingi perempuan melalui pendekatan humanistik, pendekatan ekonomi produktif dan penyadaran lingkungan hidup (Indriyati, dkk., 2009). Pemberdayaan perempuan melalui partisipasi aktif sasaran, menghasilkan manfaat bagi kesejahteraan perempuan dan keluarganya. (Indriyati dan Nugrahani, 2013).

Banyaknya ibu rumah tangga yang tidak mempunyai aktivitas ekonomi produktif dikarenakan beberapa faktor seperti tidak memiliki keterampilan, takutuntuk mengambil risiko, terlalu sibuk mengurus rumah tangga dan ekonomi rumah tangganya, kondisi perempuan yang pasif, serta karena status gender yang masih dipandang sebelah mata oleh kaum laki-laki. Demikian juga apa yang disampaikan oleh Ellen R. Sauerbrey, (2007), banyak wanita di dunia, kurang memiliki perlindungan hak-hak mereka yang paling asasi,amat kurang terdidik dansangat rentan secara ekonomi. Di banyak negera wanitajuga menghadapi kendala-kendala sosialdan budaya bagikemajuan mereka, termasuk diskriminasi, keharusan menyeimbangkan kehiduapan 
keluarga dan kebutuhan atau keinginan untuk bekerja di luar rumah, dan kendala terbesar darisemuanya adalah pendidikan. Berdasarkan beberapa permasalahan tersebut maka memperhatikan masalah perempuan menjadi sangatlah penting. Hal ini dapat dipahami, bahwa jika kualitas perempuan sebagai ibu rumah tangga diperhatikan serius maka hal ini dapat mebantu mereka untuk terlepas dari belenggu kesulitan ekonomi dan mengusahakan kehidupan ekonomis yang lebih baik.

Salah satu bidang yang menarik untuk dibahas adalah pemberdayaan ekonomi bagi perempuan. Keberdayaan perempuan di bidang ekonomi adalah salah satu indikator meningkatnya kesejahteraan. Saat perempuan menjadi kaum terdidik, mempunyai hak-hak kepemilikan, dan bebas untuk bekerja di luar rumah serta mempunyai pendapatan mandiri, inilah tanda kesejahteraan rumah tangga meningkat (Dreze and Sen, 1995).Salah satu upaya untuk meningkatkan ekonomi masyarakat adalah memberdayakan kaum perempuannya untuk bisa berwirausaha sehingga dapat ikut menjadi penambah penghasilan keluarga. Keterlibatan perempuan dalam keluarga sebagai penambah penghasilan keluarga secara tidak langsung telah turut meningkatkan kesejahteraan masyarakat secara umum.

Dengan pemberdayaan perempuan, khsusnya perempuan di pedesaan harapannya adalah agar mereka mendapat posisi yang sesuai dengan kemampuannya. Misalnya, punya keberanian untuk mengambil resiko dan keputusan dalam menghadapi suatu masalah. Selain itu, dengan dilakukannya pemberdayaan ini diharapkan akan terciptanya kemandirian. Artinya perempuan sebagai bagian dari masyarakat diharapkan mampu menolong dirinya sendiri dalam berbagai hal, terutama yang menyangkut kelangsungan hidupnya. Hal ini senada dengan hasil penelitian PSW UGM tahun 2006 yang merumuskan bahwa pada hakekatnya sasaran program pemberdayaan perempuan diarahkan untuk mengembangkan dan mematangkan dberbagai potensi yang ada pada diri perempuan yang memungkinkan dirinya dapat memanfaatkan hak dan kesempatan yang sama dengan laki-laki terhadap sumber daya pembangunan.

Pemberdayaan perempuan di pedesaan dapat dilakukanlaksanakan secara bertahap dari waktu ke waktu dan perlu kerja keras guna mewujudkan penguatan perempuan di pedesaan untuk mencapai kesejahteraan mereka. Islam sangat menghargai semangat meraih prestasi melalui kerja keras dan Islam sangat mendorong terwujudnya kesejahteraan umat. Meski demikian, tidak dapat dipungkiri bahwa kemiskinan yang mendera perempuan di desa masih menjadi maalah besar yang harus diatasi. Pemikiran tentang upaya pengentasan kemiskinan tersebut sudah banyak dan bahkan juga sebagian sudah di uji cobakan. Salah satu yang bisa menjadi alternatif diantaranya adalah dengan meningkatkan kesejahteraan perempuan di desa melalui membangun fondasi ekonomi syariah yang kuat. Untuk itu, kita harus terus mengembangkan sistem keuangan mikro yang baik, utamanya yang berbasiskan Islam.

Pemberdayaan berbasis syariah atau Islam ini menjadi penting. Khususnya pemberdayaan perempuan desa. Asas syariah ini dimaksudkan agar sebagai seorang perempuan mereka tidak melanggar kodrat mereka sebagai perempuan yang memiliki peran ganda, sebagai istri bagi suaminya, ibu bagi anaknya, dan sebagai perempuan secara utuh bagi dirinya sendiri.

Berdasarkan latar belakang diatas, maka tulisan ini dimaksudkan untuk mengkaji lebih lanjut mengenai pemberdayaan berbasis syariah, yaitu sebuah lembaga keuangan syariah "akar rumput" yang dapat dilaksanakan untuk perempuan pedesaan agar tercipta perempuan di pedesaan yang berdaya secara ekonomi. Selain itu tulisan ini juga diharapkan dapat menjadi khazanah yang menambah wawasan berpikir serta meningkatkan perhatian pembaca terhadap permasalahan yang dihadapi oleh perempuan di pedesaan Kalimantan Barat dan berusaha untuk memecahkan masalah tersebut sehingga solusi yang akan ditawarkanpun semakin beragam.

\section{MAKNA PEMBERDAYAAN}

Pemberdayaan merupakan suatu proses yang menyangkut hubungan-hubungan kekuasaan (kekuatan) yang berubah antara individu, kelompok, dan lembaga-lembaga sosial. Disamping itu, pemberdayaan juga merupakan proses perubahan pribadi karena masing-masing individu 
mengambil tindakan atas nama diri mereka sendiri dan kemudian mempertegas kembali pemahamannya terhadap dunia tempat ia tinggal (Shragge; 1993 dalam Prijono dan Pranarka;1996).

Menurut Suparjan (2003) kebijakan pemberdayaan terhadap masyarakat dibutuhkan bukan semata karena alasan kebutuhan jangka pendek, namun lebih jauh dari itu, pemberdayaan dilakukan untuk strategi kemandirian sosial ekonomi masyarakat dalam jangka panjang. Hal esensial yang perlu diperhatikan dalam proses pemberdayaan adalah bagaimana seseorang memahami essensi pemberdayaaan secara benar dan bagaimana memilih strategi yang tepat untuk pemberdayaan.

Konsep tentang pemberdayaan telah ditelaah dalam berbagai tinjauan. Pemberdayaan telah didefinisikan sebagai suatu proses (Gutierrez, 1990), sebagai suatu intervensi (Salomo, 1976), dan sebagai suatu keterampilan. Pemberdayaan juga telah dipandang sebagai suatu strategi khusus untuk memberdayakan perempuan (Browne, 1995). Selanjutnya dalam rangka menganalisis konsep pemberdayaan tersebut, menurut Sukesi (1999) dapat dirujuk pada lima dimensi, yaitu : (1) kesejahteraan, (2) akses atas sumberdaya; (3) kesadaran kritis; (4) partisipasi; dan (5) kontrol.

Mengenai pemberdayaan terhadap perempuan, khsusunya perempuan dipedesaan sebenarnya dapat dilakukan dengan berbagai cara seperti mendampingi mereka untukmengetahui potensi yang sebenarnya mereka miliki, melalui pengembangan usaha produktif atau dapat juga dilakukan dengan mendorong mereka untuk lebih kreatif dengan memberikan pemahaman terhadap perkembangan yang mukhtahir saat ini. Adapun pendekatan yang dapat dipilih dalam hal pemberdayaan perempuan di pedesaan seperti pendekatan sosiokultural, ekonomi dan lingkungan hidup. Dalam tulisan ini dipilih pendekatan berbasis ekonomi dengan prinsip syariah, hal ini diharapkan perempuan dipedesaan dapat meningkatkan penghasilanya melalui usaha ekonomi produktif untuk memenuhi kebutuhan hidup yang layak, dan dalam koridor syariah.

\section{PEMBERDAYAAN PEREMPUAN}

Diskriminasi terhadap perempuan telah menjadi dasar bagi upaya pemberdayaan perempuan. Berdasarkan hal tersebut, maka pemberdayaan perempuan bermuara dari konsep pengarusutamaan gender, kesetaraan gender, dan keadilan. Mayoux (2005: 3) mengungkapkan bahwa pengarusutamaan gender adalah sebagai berikut. "Making women's concerns and experiences integral to the design, implementation, monitoring and evaluation of policies and programmes in all political, economic and social spheres" (Mayoux, 2005: 3) Ini sejalan dengan pendapat Sen (1999) yang mengungkapkan bahwa perempuan sebagai agent of change memiliki peranan penting dalam upaya mengurangi kemiskinan. Lebih lanjut Mayoux mengungkapkan bahwa kesetaraan gender merupakan sebuah kondisi di mana perempuan memperoleh keadilan dan kesempatan yang sama, dan gender tidak lagi menjadi dasar diskriminasi dan ketidakadilan di antara masyarakat.

Pemberdayaan perempuan terfokus pada 3 issu yaitu pemberdayaan perempuan melalui kegiatan ekonomi produktif, pemberdayaan perempuan melalui kegiatan kesehatan, dan pemberdayaan perempuan melalui kegiatan pendidikan. Tujuan Program pemberdayaan perempuan adalah:1) Memenuhi kebutuhan ekonomi masyarakat bawah baik pada tingkat praktis maupun strategis. 2) Meningkatkan kesadaran masyarakat khususnya perempuan untuk menjaga kesehatan sehingga dapat menurunkan angka kematian ibu, kematian bayi, infeksi saluran reproduksi (ISR) dan penyakit menular. 3) Meningkatkan kualitas SDM Perempuan (Swasono, 2010).

Haryono Suyono (2010) menambahkan bahwa pemberdayaan perempuan sering pula disebut sebagai peningkatan kualitas hidup personal perempuan. Yaitu suatu upaya untuk memberdayakan kehidupan perempuan dalam berbagai bidang, termasuk ekonomi, edukasi atau pendidikan, sosial, komunikasi, informasi, dan lain sebagainya agar mereka terbebas dari belenggu kemiskinan dan keterbelakangan.

Kabeer (2001) menyatakan bahwa terdapat lima unsur utama yang perlu diperhatikan dalam proses pemberdayaan perempuan, yaitu sebagai berikut. 


\section{Welfare (Kesejabteraan)}

Aspek ini dapat dikatakan salah satu aspek yang penting dalam upaya peningkatan pemberdayaan perempuan. Tidak dapat dipungkiri bahwa dalam akses terhadap kesejahteraan, perempuan menempati posisi yang tidak menguntungkan. Kesejahteraan ini dibagi ke dalam tiga unsur utama berikut (Claros and Zahidi, 2005: 2-5).

2. Access (Akses)

Dalam hal ini akses diartikan sebagai kemampuan perempuan untuk dapat memperoleh akses terhadap berbagai sumber daya produktif seperti tanah, pelatihan, fasilitas pemasaran, tenaga kerja, dan semua pelayanan publik yang setara.

3. Consientisation (Konsientisasi)

Pemahaman atas perbedaan peran jenis kelamin dan peran gender.

4. Participation (Partisipasi)

Kesetaraan partisipasi perempuan dalam proses pembuatan keputusan, pembuatan kebijakan, perencanaan, dan administrasi. Partisipasi ini merujuk pada keterwakilan perempuan yang setara dalam struktur pembuatan keputusan baik secara formal maupun informal, dan suara mereka dalam penformulasian kebijakan mempengaruhi masyarakat mereka (Claros dan Zahidi, 2005: 4).

5. Equality of Control (Kesetaraan dalam kekuasaan)

Kesetaraan dalam kekuasaan atas faktor produksi, dan distribusi keuntungan sehingga baik perempuan maupun laki-laki berada dalam posisi yang dominan.

Pada dasarnya pemberdayaan perempuan merupakan proses kesadaran dan pembentukan kapasitas (capacity building) terhadap partisipasi yang lebih besar untuk memiliki kekuasaan dan pengawasan dalam pembuatan keputusan dan transformasi (transformation action) agar perempuan mampu menghasilkan sesuatu yang bermanfaat (Karl,1995). Sehingga pada akhirnya pemberdayaan perempuan ini sampai pada memungkinkan setiap perempuan mampu memenuhi pilihannya sendiri secara bijaksana.

Adapun yang dapat dijadikan indikator dalam sukses atau tidaknya pemberdayaan perempuan dalam rangka dilakukan untuk menunjang dan mempercepat tercapainya kualitas hidup dan mitra kesejajaran antara laki-laki dan perempuan adalah sebagai berikut: 1 . Adanya sarana yang memadai guna mendukung perempuan 2. Adanya peningkatan partisipasi dan semangat kaum perempuan untuk berusaha lebih kuat bagi diri mereka. Jika ini telah terealisasi, maka perempuan benar-benar telah terberdayakan.

\section{PEMBERDAYAAN PEREMPUAN DALAM PERSFEKTIF SYARIAH}

Mengkaji perempuan tidak dapat dilepaskan dari nilai atau ketentuanyang membedakan identitas sosial laki-laki dan perempuan, serta apa yangharus dilakukan oleh perempuan dan apa yang harus dilakukan oleh laki-laki dalam ekonomi, politik, sosial dan budaya baik dalam kehidupankeluarga, masyarakat dan bangsa (Edi Suharto, 2006). Menurut Aritonang pemberdayaan perempuan adalah upaya peningkatan kemampuan perempuan dalam mengembangkan kapasitas dan keterampilannya untuk meraih akses dan penguasaan terhadap, antara lain: posisi pengambil keputusan, sumber danstruktur atau jalur yang menunjang.

Islam sendiri menempatkan kedudukan perempuan pada proporsinya dengan mengakui kemanusiaan perempuan dan mengikis habis kegelapan yang dialami perempuan sepanjang sejarah serta menjamin hak-hak perempuan. Untuk menjelaskan kedudukan perempuan dalam hukum Islam, dasar hukum yang harus dipegangi adalah kedua sumber utama hukum Islam, yaitu Alquran dan Sunnah (hadis). Dari dua sumber inilah diperoleh prinsip-prinsip yang pasti untuk melihat kedudukan perempuan dalam Islam (Alhibri, 2001).

Ayat Alquran yang dengan tegas melihat kesejajaran kaum perempuan dengan kaum lakilaki adalah QS. al-Lail (92): 3-10 yang menyebut kaum laki-laki dan perempuan dalam qasam (sumpah) yang merupakan bukti (qarinah) bahwa Allah melihat persamaan antara keduanya. Ayat- 
ayat tersebut mengisyaratkan bahwa perbedaan manusia hanya terletak pada aksinya, apakah baik atau buruk, dengan tidak melihat jenis kelaminnya. Ayat tersebut juga merupakan deklarasi Alquran pertama terhadap prinsip taklif baik laki-laki maupun perempuan dalam persoalan dunia dan agama; juga merupakan prinsip balasan bagi usaha dari laki-laki dan perempuan berdasarkan aktivitas kerja mereka; dan merupakan pendeklarasian persamaan antara laki-laki dan perempuan dalam kecenderungan untuk melakukan aktivitas (Shalih, 2001: 40).

Lily (2002) menyampaikan pernyataan yangkurang lebih mendukung pernyataan dari Shalih (2001) namun Lily membahas lebih kepada pencapaain individu yang tidak hanya difokuskan kepada laki-laki saja. Laki-laki dan perempuan memiliki hak yang sama untuk meraih prestasi yang maksimum. Hal ini ditegaskan secara khusus dalam tiga ayat, yakni Ali Imran 195, al- Nisa' 124, an-Nahl 97. Ketiganya mengisyaratkan konsep kesetaraan gender yang ideal dan memberikan ketegasan bahwa prestasi individual, baik dalam bidang spiritual maupun karier profesional, tidak mesti didominasi oleh satu jenis kelamin saja.

Sedangkan munculnya ketidakadilan terhadap perempuan dengan dalih agama dewasa ini lebih disebabkan karena adanya implementasi yang salah satu dari ajaran agama tersebut yang disebabkan oleh pengaruh faktor sejarah, lingkungan budaya dan tradisi yang patriarkhi di dalam masyarakat, sehingga menimbulkan sikap dan perilaku individual yang secara turun temurun menentukan status kaum perempuan dan ketimpangan gender tersebut.

Dalam sejarah Islam tercatat adanya perempuan (muslimah) turut berperan aktif dan signifikan membangun peradaban, melakukan aktivitas sosial ekonomi, politik dan pendidikan serta perjuangan untuk kemaslahatan umat (Hasanah, 2011). Misalnya Balqis binti Syarahil. Ia adalah ratu dari negeri Saba salah satu dari kerajaan Yaman. Balqis adalah perempuan yang berwibawa, cantik sekaligus cerdas dan seorang orator ulung. Sebagai seorang diplomat yang cerdas, Balqis memiliki strategi-strategi yang jitu dalam menjalani karier politiknya sehingga mampu memperluas daerah kekuasaannya. Kecerdasan Balqis sangat tampak ketika Ia memperluas daerah kekuasaanya dengan menaklukkan beberapa daerah, sebelum bertindak Balqis mengumpulkan berbagai informasi tentang kelemahan sasaran penaklukan sehingga kemenangan bisa diraihnya. Negeri yang dipimpin ratu Balqis merupakan negeri yang makmur dan rakyatnya sangat patuh pada peraturan hukum yang ditetapkan sang ratu. Hal tersebut sebagai cermin bahwa sang ratu adalah sosok perempuan yang tidak diragukan lagi keilmuannya.

Mengenai perempuan yang memberdayakan dirinya dengan bekerja Islam pun mengaturnya dan tidak ada larangan untuk itu. Qardhawi dalam Hasanah (2011) mengkategorikan hukum perempuan bekerja di luar rumah atau melakukan aktivitas adalah jaiz (dibolehkan) dan dapat sebagai sunah atau bahkan kewajiban (wajib) karena tuntutan (membutuhkannya), misalnya pada janda yang diceraikan suaminya, dan untuk karena untuk membantu ekonomi suami atau keluarga. Perempuan cenderung memiliki kemandirian apabila mempunyai pendapatan dan kegiatan ekonomi (Sadli, 1991).

Pemberdayaan perempuan dalam persektif Islam sendiri memandang bahwa perempuan adalah bagian dari masyarakat. Islam pun menganjurkan bahwa wanita harus melakukan interaksi dan aktivitas dalam kehidupan masyarakat untuk menunaikan perannya sebagai partner laki-laki dalam memakmurkan bumi dan merealisasikan sebuah pemberdayaan. Islam telah menjaga hakhak sipil perempuan dengan utuh, memelihara kelayakannya dalam menjalankan tugas-tugasnya, melakukan beragam transaksi seperti jual-beli, gadai, hibah, wasiat, dan beberapa bentuk transaksi yang lain yang bisa dikerjakan seorang perempuan.

\section{FENOMENA PEREMPUAN DI PEDESEAAN}

Gusti Kanjeng Ratu Hemas dalam talkshow dengan tema "Empower Rural Women: End Hunger and Poverty" (2012) mengatakan bahwa terdapat tiga masalah utama yang dihadapi oleh perempuan pedesaan yang berkaitan dengan diskriminasi hak dan gender, yaitu:

\section{Kesehatan}


Di pedesaan, kesehatan perempuan belum terlalu dijamin dan diutamakan dibandingkan kaum pria. Alasannya adalah karena lingkungan adat yang masih dipertahankan dan selalu mengutamakan pria di atas perempuan, termasuk untuk akses kesehatan. Sebagai kepala keluarga yang sehat, pria dianggap bisa menjadi jaminan keluarga yang juga akan sehat.

\section{Pendidikan}

Persepsi bahwa perempuan tidak perlu berpendidikan tinggi, karena perempuan hanya akan menghabiskan waktunya di dapur dan mengurus anak. Persepsi diatas masih melekat di masyarakat pedesaan sehingga bagi masyarakat di pedesaan, pendidikan bagi perempuan belum dianggap penting. Mereka lebih mengutamakan jenjang pendidikan yang tinggi untuk anak laki-laki dibanding anak perempuan.

\section{Ekonomi}

Dalam hal ekonomi, perempuan tidak dianggap sebagai penopang ekonomi yang sah. "Misalkan pada perempuan petani. Meskipun mereka melakukan pekerjaan seperti petani lainnya, mereka tidak dibayar. Karena mereka dianggap sekadar membantu suaminya bekerja, sehingga yang dibayarkan adalah upah sang suami," tukasnya.

Hayati (2007) menyampaikan hal yang senada yaitu telah terjadi beberapa kasus ketidakadilan terhadap wanita, misalnya diskriminasi terhadap pendidikan, lapangan pekerjaan. Adanya eksploitasi pemaksaan, stereotipe negatif, sub-ordinasi, kekerasan dibandingkan dengan laki-laki bahkan beban kerja wanita lebih berat dan panjang, namun tidak mendapatkan penghargaan atas pekerjaannya di luar rumah tangga, dan wanita sering mengalami perlakuan yang tidak menyenangkan (Guire dan Popokin 1990).

Pemberdayaan perempuan di pedesaan sudah seharusnya menjadi perhatian bagi kita semua, dengan cara meningkatkan kualitasnya. Hal ini diartikan bahwa jika kualitas perempuan di pedesaan ditingkatkan tentu adanya hubungan timbal balik, yaitu disamping dapat meningkatkan peran dalam menjalankan fungsi keluarga dan diharapkan adanya peningkatan ekonomi keluarga akhinya akan berdampak pada kesejahteraan keluarga dan pembangunan bagi desanya. Hal ini mengingat peran wanita dalam pembangunan tidaklah kecil dan merupakan bagian yang tak dapat dipisahkan dalam pembangunan Nasional. Mereka memberikan sumbangan yang besar bagi kelangsungan ekonomi dan kesejahteraan rumah tangga serta masyarakat, berupaya mengentaskan golongan masyarakat yang masih hidup di bawah garis kemiskinan,termasuk ibu-ibu rumah tangga.

\section{MODEL PEMBERDAYAAN GRASSROOTS MICROFINANCE SHARIAH}

Grassroots Microfinance adalah pembiayaan yang diberikan untukkeluarga miskin namun produktif. Istilah grassroots dalam bahasa Indonesia sendiri berarti akar rumput.Istilah "akar rumput" menjadi symbol orang miskin atau masyarakat kelasbawah yang memiliki penghasilan rendah. Masyarakat miskin ataumasyarakat yang berpenghasilan rendah belum memiliki asset yang layakuntuk dijadikan sebagai agunan. Usahanya relatif belum permanen, dan pola cash flownya juga tidak tetap. Sifat ini lah yang membuat mereka sulit untuk dijangkau oleh commercial microfinanceseperti perbankan. Tidak bisa dipungkiri bahwa kenyataan dalam aktivitas bisinis terutama yang bersifat permodalan perbankan selalu mengedepankan anggunan atau jaminan. Kenyataan inilah yang kemudian dapat menghalangi usaha kecil milik masyarakat miskin sulit untuk berkembang bahkan sekadar hanya untuk bertahan.

Ciri-ciri grassroot microfinance, yaitu:1) ada sistemtanggung renteng dan mekinisme tanggung jawab; 2) pembiayaan dalambentuk kelompok; 3) jumlah platfon pembiayaan relatf kecil; 4) ada penggunaansanksi sosial; 5) pembayarankembali dengan sistem angsuran; 6)ada pertemuan kelompok; 7) terdapat petugas lapangan yang bertangungjawab secara rutin untuk membantu setiap kelompok dalam upaya untuk meningkatkan pernghasilan komunitas mereka.

Lalu bagaimana dengan koperasi simpan pinjam khusus wanita yang sudah lama berkembang. Walaupun dalam perkembangannya koperasi simpan pinjam wanita lebih mudah kita dapati, namun kegiatan simpan pinjam khusus wanita dalam perkembangannya masih 
mnggunakan sistem konvensional yaitu sistembunga dalam simpanan maupun pinjaman. Bunga uang dalam simpan pinjam ini menyebabkan ketertarikan karena adanya kepastian hasil. Sementara setiap usaha tidak ada yang mampu menjamin hasilnya karena setiap usaha memiliki resiko untung, rugimaupun balik modal dalam jumlah besar, kecil maupun sedang. Apa lagi sistem bunga pada peminjaman, sejurus proses memang lebih mudah, namun kelebihan yang harus dibayar atas pinjaman tersebutlah yang pada akhirnya akan mencekik peminjamnya. Perlahan, namun pasti justru akan mematikan usaha, karena jika tidak mampu membayar, bunga atas pokok pinjaman akan terus meningkat.

Bunga telah menyebabkan semakin jauh jarak antara pembangunandan tujuan yang akan dicapai. Hal ini dikemukakan Umer Chapra (1996), bunga juga merusak tujuan-tujuan yang ingin di dapat, pertumbuhan ekonomi, produktivitas dan stabilitas ekonomi. Hal senada diuangkapkan oleh Roy Davies dan Glyn Davies, dalam bukunya A History of Moneyfrom Ancient Times to the Present Day (1996) mengatakan bahwa bunga telah memberi andil besar dalam lebih dari 20 krisis yang terjadi sepanjang abad 20. Sementara di Indonesia sendiri mengenai bunga ini telah diharamkan oleh Majlis Ulama Indonesia (MUI) dengan di terbitkannya Fatwa MUI No. 1 Tahun 2004 karena bunga termasuk kategori riba yang dilarang dalam al-Qur'an.

Dalam pengelelolaan serta pelaksanaanya Grassroots Microfinance Syariahakan berdasarkan pada prinsip syariah yaitu berlandaskan pada alquran dan hadist dengan minimal memiliki empat divisi dibawah manajer atau kepala divisi yaitu, divisi operasional, divisi akuntansi divisi investasi dan divisi pemberdayaan. Masing-masing divisi ini sangat urgen keberadaannya dalam pengelolaan dana. Tugas utama divisi operasional sekaligus divisi pelayanan adalah mencari peserta sebanyak-banyaknya, dalam hal ini adalah perempuaan di pedesaan, termasuklah didalamnya ibu rumah tangga yang memiliki keinginan untuk lebih produktif. Dari pencarian, penerimaan peserta inilah nantinya akan diperoleh dana yang siap dicadangkan sebagai pendapatan dan dana yang nantinya akan digulirkan bagi pesertanya untuk memulai usaha ketika memasuki masa purna bakti.

Selanjutnya divisi akuntansi bertugas mengatur keuangan perusahaan, pengaturan ini diimplementasikan melalui pembedaan rekening untuk masing-masing dana Pemisahan ini dilakukan berdasarkan karakteristik yang berbeda-beda, maka berbeda pula dalam perlakuan akuntasinya.

Divisi investasi memiliki fungsi untuk melakukan pengembangan dana yang bersumber dari iuran yang telah dibayar oleh peseta dalam bentuk peryertaan langsung atau yang lainnya, tentunya yang menjadi dasar dalam divisi ini adalah investasi yang sehat, berisiko gagal yang kecil dan sesuai dengan prinsip syariah tentunya, agar tidak ada ke khawatiran bagi peserta mengenai sumber hukumnya, apakah halal atau haram.

Divisi pemberdayaan memiliki fungsi yaitu, analisis usaha peserta yang akan dibiayai, fungsi pendampingan dan fungsi lain yang berkaitan dengan pemberdayaan agar dana yang dikeluarkan tetap produktif dan terjamin kerberlangsungan usahanya.

Dana iuran yang diperoleh dari setiap peserta akan dibagi secara porposional yaitu pertama untuk ujrah sebagai sumber pendapatan bagi pengelola, kedua, manfaat yaitu sebagai pencadangan pendapatan yang nantinya akan diperoleh langsung oleh peserta, ketiga dana untuk program pemberdayaan dan investasi yang nantinya bagi hasil yang diperoleh akan menjadi penambah manfaaat bagi peserta.

Permberdayaan yang akan dilakukan oleh pengelola akan menggunakan akad mudharabah dan akad musyarakah dengan prinsip bagi hasil. Adapun yang bersifat sosial (ta'awnn) dapat berupa akad qard al-hasan. Akad ini untuk memberikan bantuan apabila peserta membutuhkan pendanaan bukan untuk konsumsi maupun produksi tapi untuk kepentingan biaya sakit, biaya musibah dan sebagainya.

Setiap peserta yang mendapatakan dana pemberdayaan wajib untuk memulai usahanya. Dana pemberdayaan ini berbentuk pembiayaan yang bebas riba, pengguna dana hanya berkewajiban untuk mengembalikan pokoknya dan bagi hasil terhadap keuntungan usaha sesuai 
dengan kesepakatan. Pendapatan atas bagi hasil tersebut akan digunakan untuk menambah manfaat yang akan diperoleh peserta. Jangka waktu pembiayaan dimulai dari 12 (dua belas) bulan sampai dengan 120 (seratus dua puluh) bulan dengan plaform pembiayaan untuk permulaan maksimal 20 (dua puluh) juta dan akan terus meningkat sesuai dengan perkembangan badan pengelola.

Setelah usaha berjalan dan mendapatkan keuntungan yang telah dibagi hasil maka keuntungan ini sepenuhnya menjadi hak milik peserta dan menjadi sumber penghasilan baru bagi peserta. Dengan mekanisme pengelolaan seperti ini, maka tidak hanya pengelola yang aktif untuk mesejahterakan pesertanya tapi peserta sendiri pun aktif untuk tetap produktif, mandiri, dan berdaya walapun peserta tinggal di pedesaan.

Selanjutnya divisi investasi akan melakukan investasi pada sektor-sektor yang diperbolehkan oleh syariah, artinya jenis investasi yang dipilih adalah yang sehat dan aman secara pertimbangan ekonomi juga halal lagi baik berdasarkan pertimbangan syariah. Pola antara investasi dan pemberdayaan ini harus diatur sebaik mungkin agar operasional pengelola bisa terus beroperasi, perberdayaan melalui penyaluran dana pembiayaan tetap dalam proporsi yang ideal.

Sebagaimana yang telah dijelaskan mengenai ciri-ciri grassroot microfinance, dimana diantaranya pembiayaan akan diberikan dalam bentuk kelompok, oleh karena itu pola pemberdayaan yang akan dilakukan oleh pengelola Grassroots Microfinance Syariah adalah dengan, pertama peserta yang merupakan perempuan di pedesaan dengan ekonomi lemah diharuskan untuk membentuk kelompok kerja minimal lima orang, hal ini dimaksudkan agar penanggungan yang akan dibebankan akan lebih ringan. Kelompok kerja yang telah terbentuk kemudian akan didorong oleh pengelelola untuk mengajukan ide usaha, selanjutnya divisi pemberdayaan melakukan review dan pembinaan, serta ikut mengkonsep untuk mematang ide usaha yang diajukan oleh peserta.

Setelah menghasilkann konsep usaha yang matang dan kelompok kerja yang terbina dari sisi kemampuan untuk mengelola usaha, maka yang akan dilakukan oleh pengelelola selanjutnya adalah menyiapkan permodalan yang diambil dari dana iuran peserta yang sudah dibagi secara porposional untuk dana pemberdayaan perserta lalu diserahkan kepada peserta yang siap menjalankan usaha. Akad yang digunakan adalah akad mudhrabah atau musyarakah sesuai kesepakatan yang wajib dikembalikan dengan sistem bagi hasil. Setelah nasabah paham dengan akad yang digunakan dana siap digunakan untuk memulai usaha.Setelah usaha berjalan selanjutnya dilakukan monitoring oleh divisi pemberdayaan secara kontinyu untuk memastikan bahwa usaha yang dijalan kan akan memiliki siklus ekonomi yang panjang.

Dengan langkah ini semua dan dengan sinergitas yang baik, maka akan terciptalah peserta dalam hal ini perempuan dipedesaan yang lebih produktif, mandiri, aman dan berdaya. Pola pikir terhadap perempuan yang dianggap hanya sebagai second gender pun akan hilang, sebaliknya maka akan terciptalah perempuan pedesaan yang lebih mandiri dan berani mengambil risiko sampai akhirnya memiliki sumber penghasilan baru yang berksinambungan.

\section{PENUTUP}

Masih banyak wanita di dunia, kurang memiliki perlindungan hak-hak mereka yang paling asasi, kurang terdidik dan sangat rentan secara ekonomi. Dibanyak negera wanita juga menghadapi kendala-kendala sosialdan budaya bagi kemajuan mereka. Disamping itu Adanya eksploitasi pemaksaan, stereotipe negatif, sub-ordinasi, kekerasan dibandingkan dengan laki-laki bahkan beban kerja wanita lebih berat dan panjang, namun tidak mendapatkan penghargaan atas pekerjaannya di luar rumah tangga, dan wanita sering mengalamiperlakuanyang tidak menyenangkan (Guire dan Popokin 1990).

Dariaspek gender masih tampak adanya kesenjangan, disebabkan masih kuatnya budaya patriarkhi. Hal ini dapat dilihat dari: (1) Laki-laki masih memiliki kontrol yang kuat di segala bidang kehidupan, (2) Partisipasi perempuan nampaknya sudah mulai dilihat, namun perempuan tetap 
tidak ada keberanian, sehingga kurang memiliki kekuatan personal. (3) Penyadaran perempuan masih bersifat kultural,pembagian kerja gender dianggap sebagai takdir.

Pemberdayaan perempuan khsusnya perempuan di pedesaan mutlak diperlukan. Harapannya adalah agar perempuan dipedesaan mendapat posisi yang sesuai dengan kemampuannya. Misalnya, punya keberanian untuk mengambil resiko dan keputusan dalam menghadapi suatu masalah. Selain itu, dengan dilakukannya pemberdayaan ini diharapkan akan terciptanya kemandirian. Artinya perempuan sebagai bagian dari masyarakat diharapkan mampu menolong dirinya sendiri dalam berbagai hal, terutama yang menyangkut kelangsungan hidupnya.

Perempuan dapat berinovasi dengan menerapkan tata kelola simpan pinjam yang lebih menekankan pada nilai-nilai keadilan yaitu simpan pinjam syariah. Hal ini dapat direalisasikan dengan menerapkan akad kerjasama. Jenis akad ini merupakan akad yang komersil atau menghasilkan keuntungan yang dapat dijadikan sebagai dana pendapatan dan juga sebagai dana pengembangan untuk pengelelola.

Model Grassroots Microfinance Syariah berbasis peningkatan produktifitas perempuan di pedesaan sangat cocok untuk mengatasi masalah yang dihadapi perempuan dipedesaan yang selama ini harus dihadapkan pada ketikak beranian dalam mengambil risiko, dan kurang memiliki tempat dari sisi ekonomi karena tidak berhasil mencari sumber penghasilan sendiri. Model ini dinilai tepat karena memadukan solusi untuk dua masalah dalam satu konten yaitu melalui permberian permodalandan pendampingan. Agar dapat berjalan sesuai dengan rencana maka tata kelola Model Grassroots Microfinance Syariah haruslah memenuhi prinsip keterbukaan (transparancy), akuntabilitas (accountability), pertanggungjawaban (responsibility), kemandirian (indepedency I serta kesetaraan dan kewajaran (fairness).

Modal kerja yang disalurkan merupakan modal kerja dengan hanyapengembalian pokok dan sistem bagi hasil sehingga peserta yang mengunakan modal ini tidak akan dibebankan dengan pengembalian kelebihan karena pinjaman ini bebas dari unsur riba. Keberadaan Model Grassroots Microfinance Syariab ini juga dapat dijadikan sarana penciptaan peserta yang lebih porduktif sehingga peserta dapat memeroleh penghasilan yang berksinambungan.

Model Grassroots Microfinance Syariah yang coba dikembangkan ini patut dicontoh oleh lembaga keuangan syariah lainnya baik itu yang bersifat mikro maupun perbankan karena konsep ini merupakan upaya meningkatkan taraf hidup peserta dan mendorong tumbuhnya Usaha Mikro dan Kecil yang kuat dan tangguh di Indonesia.

Kajian ini belumlah sempurna, maka sangat disarankan bagi peneliti serta akademisi agar dapat membuat kajian-kajian sejenis dalam rangka menambah koleksi khazanah ilmiah secara khusus pada keilmuan pengelolaan lembaga keuangan mikro syariahdan pada model permberdayaan perempuan yang tentunya tidak hanya disisi manusia tapi juga baik di sisi Tuhan.

\section{DAFTAR PUSTAKA}

Al-Hibri, Azizah. (2001). "Landasan Qur'ani Mengenai Hak-hak Perempuan Muslim pada Abad Ke-21”Yogyakarta: Sunan Kalijaga Press.

Arief Budiman, Pergeseran Peran Laki-laki dalam Rumah Tangga: Suatu Tinjauan Sosiologis, (Yogyakarta: Pustaka Pelajar, 1998)

Browne, C. V. 1995. "Empowerment in Social Work Practice with Older Woman”. Social Work, 40, 358-364

Claros, Augusto Lopez dan Saadia Zahidi. 2005. Woman Empowerment: Measuring The Global Gender Gap. Worl Economic Forum. Diakses dari situs : www.weforum.org 
Didin S, Damanhuri, Pilar-pilar Reformasi Ekonomi Politik, (Yogyakarta: Pustaka Hidayah, 1999)

Dreze, Jean dan Sen, Amartya. The Amartya Sen and Jean Drèze Omnibus:(comprising) Poverty and Famines;Hunger and Public Action; India: Economic Development and Social Opportunity. Oxford University Press. 1999.

Edi Suharto. Membangun Masyarakat Membangun Rakyat, Kajian Strategis PembangunanKesejabteraan Sosial dan Pekerjaan Sosial. (Bandung: Refika Aditama, 2006)

Framework. Aga Khan Foundation. Diakses dari situs http://www.genfinances.net

Friedman, John. (1992). Empowerment People: The Politic and Alternative Development. Massachusetts Cambridge USA: Blackwell Publishers.

Gutierrez, L. 1990. "Working with Woman of Color”. Social Work.

Haryono Suyono, Ekonomi Keluarga Pilar Utama Keluarga Sejahtera, 47

Hasanatul Jannah, 2011, Pemberdayaan Perempuan Dalam Spiritualitas Islam (Suatu Upaya Menjadikan Perempuan Produktif) KARSA, Vol. 19 No. 2 Tahun 2011.

Hayati,2007.LensaJenderBidangPendidikan.RisalahSosialisasiPUGpadaPerguruan TinggiseNTB, Mataram26 Nopember2007.

Henry Sandee, Brahmantio Isdijoso, dan Sri Sulandjari, "SME clu sters in Indonesia: An Analysis of Growth Dynamics and Employment Conditions", Report to the ILO, Jakarta, 2002

Hulme, David and Marx Turner. (1990). Sociology and Development:Theories, Policies ang Practice. London: Wheatsheaf.

Jim Ife, Community Development 2 (Sydney: Pearson Education Australia Pty Ltd,2002)

Kabeer, Naila. Reflections on The Measurement of Women's Empowerment in Discussing Women Empowerment: Theory and Practices. Sida Studies No3 Journal. 2001

Lily Zakiyah Munir, Memposisikan Kodrat Perempuan dan Perubahan dalam Perspektif Islam, 2002.

Mayoux, Linda (2001a), Gender Equity, Equality and Women's Empoworment; Princple, Development and Framework, Aga Khan Foundation. Diakses dari situs http://www.genfinance.net

Megawangi, Membiarkan berbeda, Sudut Pandang Baru Relasi Gender, (Jakarta: Mizan, 1999)

Murniati Ruslan, 2010, Pemberdayaan Perempuan Dalam Dimensi Pembangunan Berbasis Gender ; Musawa, Vol. 2, No. 1, Juni 2010:79-96

N.Oneng Nurul Bariyah. Total Quality Management Zakat: Prinsip dan PraktikPemberdayaan Ekonomi. Jakarta: Wahana Kardofa, 2012) 
Prijono dan Pranaka. (1996). Pemberdayaan (Konsep, Kebijakan dan Implementasi). Jakarta: CSIS.

Rita Yuliana 1 Pemberdayaan Perempuan Perdesaan Dalam Pembangunan Wacana Vol. 12No. 3 Juli 2009

Saptandari, Pinky.2010, Lim Tingkat Pemberdayaan Perempuan, Jurnal Masyarakat Kebudayaan dan Politik. Vol.12 No 2. Hal 33-38

Sauerbrey, Ellen R, 2007.Bekerja untuk.Wanita. HTT://Usinfo.State.Goiv/Journals.HTM

Seminar Nasional Universitas PGRI Yogyakarta 2015 Pemberdayaan Perempuan Desa Untuk Mengurangi Kemiskinan

Setiana Lucie, Teknik Penyuluban dan Pemberdayaan Masyarakat, (Bogor: Ghalia Indonesia, 2005), hlm. 5-6.

Shalih, Su’ad. Ibrahim. (2001). "Kedudukan Perempuan dalam Islam”, dalam Yogyakarta: Sunan Kalijaga Press

Siti Rohmah Model Pemberdayaan Ekonomi PerempuanMelalui Grassroot Microfinance Syariah Sawwa Volume 10, Nomor 1, Oktober 2014

Sosalia Indriyati Saptatiningsih Model Pemberdayaan Ekonomi Keluarga Pengembang Ekonomi Lokal Melalui Sistem Kemitraan Bisnis Islam Berbasis Mompreneur

Sri-Edi Swasono, Kembali Ke Pasal 33 UUD 1945 Menolak Neoliberalisme, (Yayasan Hatta, 2010)

Sukesi, K. 1999. "Beberapa Alat Kajian Jender dalam Pembangunan". Makalah Yang disajikan dalam Kajian Jender dalam Pendidikan dan Peng-ajaran Malang: Puslit-Lemlit IKIP Malang.

Suparjan dan Suyatno, Pengembangan Masyarakat dari Pembangunan SampaiPemberdayaan, (Yogyakarta: Social Agency, 2003)

Tim Peneliti PSW UGM, Profil GenderDevelopment Index (GDI) Dan GenderEmpowerment Measure (GEM) KabupatenSleman, PSW UGM Kerjasama dengan Pemda Kabupaten Sleman.

Usman Sunyoto, Pembangunan dan Pemberdayaan Masyarakat, (Yogyakarta: Pustaka Pelajar, 1998)

Yatmo, Mardi Hutomo. (2000) Pemberdayaan Masyarakat dalam Bidang Ekonomi: Tinjauan Teoretik dan Implementasi, Naskah No. 20.

Yusuf Qardhawi, "Fatwa-fatwa Kontemporer. Apa saja yang Boleh Dikerjakan Wanita?”, dalam http://dir.groups. yahoo.com/group/wanita-muslimah/message/296 (8 Oktober 2016). 